\title{
Front Matter: Volume 9017
}

, "Front Matter: Volume 9017," Proc. SPIE 9017, Visualization and Data Analysis 2014, 901701 (3 February 2014); doi: 10.1117/12.2052776

SPIE Event: IS\&T/SPIE Electronic Imaging, 2014, San Francisco, California, United SPIE. States 


\title{
PROCEEDINGS \\ IS\&T / SPIE \\ Electronic Imaging \\ SCIENCE AND TECHNOLOGY
}

\section{Visualization and Data Analysis 2014}

\author{
Pak Chung Wong \\ David L. Kao \\ Ming C. Hao \\ Chaomei Chen \\ Editors
}

3-5 February 2014

San Francisco, California, United States

Sponsored by

IS\&T-The Society for Imaging Science and Technology

SPIE

Cosponsored by

Kitware Inc. (United States)

Published by

SPIE 
The papers included in this volume were part of the technical conference cited on the cover and title page. Papers were selected and subject to review by the editors and conference program committee. Some conference presentations may not be available for publication. The papers published in these proceedings reflect the work and thoughts of the authors and are published herein as submitted. The publishers are not responsible for the validity of the information or for any outcomes resulting from reliance thereon.

Please use the following format to cite material from this book:

Author(s), "Title of Paper," in Visualization and Data Analysis 2014, edited by Pak Chung Wong, David L. Kao, Ming C. Hao, Chaomei Chen, Proceedings of SPIE-IS\&T Electronic Imaging, SPIE Vol. 9017. Article CID Number (2014)

ISSN: 0277-786X

ISBN: 9780819499349

Copublished by

SPIE

P.O. Box 10, Bellingham, Washington 98227-0010 USA

Telephone +1 3606763290 (Pacific Time) · Fax +1 3606471445

SPIE.org

and

IS\&T-The Society for Imaging Science and Technology

7003 Kilworth Lane, Springfield, Virginia, 22151 USA

Telephone +1 7036429090 (Eastern Time) · Fax +1 7036429094

imaging.org

Copyright @ 2014, Society of Photo-Optical Instrumentation Engineers and The Society for Imaging Science and Technology.

Copying of material in this book for internal or personal use, or for the internal or personal use of specific clients, beyond the fair use provisions granted by the U.S. Copyright Law is authorized by the publishers subject to payment of copying fees. The Transactional Reporting Service base fee for this volume is $\$ 18.00$ per article (or portion thereof), which should be paid directly to the Copyright Clearance Center (CCC), 222 Rosewood Drive, Danvers, MA 01923. Payment may also be made electronically through CCC Online at copyright.com. Other copying for republication, resale, advertising or promotion, or any form of systematic or multiple reproduction of any material in this book is prohibited except with permission in writing from the publisher. The CCC fee code is 0277-786X/14/\$18.00.

Printed in the United States of America.

Paper Numbering: Proceedings of SPIE follow an e-First publication model, with papers published first online and then in print and on CD-ROM. Papers are published as they are submitted and meet publication criteria. A unique, consistent, permanent citation identifier (CID) number is assigned to each article at the time of the first publication. Utilization of CIDs allows articles to be fully citable as soon as they are published online, and connects the same identifier to all online, print, and electronic versions of the publication. SPIE uses a six-digit CID article numbering system in which:

- The first four digits correspond to the SPIE volume number.

- The last two digits indicate publication order within the volume using a Base 36 numbering

system employing both numerals and letters. These two-number sets start with 00, 01, 02, 03, 04, $05,06,07,08,09,0 A, 0 B \ldots 0 Z$, followed by 10-1Z, 20-2Z, etc.

The CID Number appears on each page of the manuscript. The complete citation is used on the first page, and an abbreviated version on subsequent pages. Numbers in the index correspond to the last two digits of the six-digit CID Number. 


\section{Contents}

vii Conference Committee

xi Introduction

\section{SESSION 1 BIOMEDICAL VISUALIZATION}

901702 FilooT: a visualization tool for exploring genomic data [9017-1]

M. Zeinaly, M. Soltangheis, C. D. Shaw, Simon Fraser Univ. (Canada)

901703 A framework for analysis of the upper airway from real-time MRI sequences [9017-2]

S. Silva, A. Teixeira, Univ. de Aveiro (Portugal)

\section{SESSION 2 CYBER SECURITY AND VISUALIZATION}

901704 VAFLE: visual analytics of firewall log events [9017-3]

M. Ghoniem, Ctr. de Recherche Public - Gabriel Lippmann (Luxembourg);

G. Shurkhovetskyy, Modern Sciences and Arts Univ. (Egypt); A. Bahey, Nile Univ. (Egypt);

B. Otjacques, Ctr. de Recherche Public - Gabriel Lippmann (Luxembourg)

901705 Configurable IP-space maps for large-scale, multi-source network data visual analysis and correlation (Best Paper Award) [9017-4]

S. Miserendino, C. Maynard, W. Freeman, Northrop Grumman Corp. (United States)

\section{SESSION 3 TEXT DATA MINING AND VISUALIZATION}

901706 The CZSaw notes case study [9017-5]

E. Lee, A. Gupta, D. Darvill, J. Dill, C. D. Shaw, R. Woodbury, Simon Fraser Univ. (Canada)

901707 Linked visual analysis of structured datasets and document collections [9017-6]

S. Kolman, E. Galkina, A. S. Dufilie, Y. F. Luo, V. Gupta, G. Grinstein, Univ. of Massachusetts Lowell (United States)

901708 A reference web architecture and patterns for real-time visual analytics on large streaming data [9017-7]

E. Kandogan, D. Soroker, S. Rohall, P. Bak, F. van Ham, J. LU, H.-J. Ship, IBM Research

(United States); C.-F. Wang, Univ. of California, Davis (United States); J. Lai, IBM Research

(United States) 
901709 Visualizing confusion matrices for multidimensional signal detection correlational methods [9017-8]

Y. Zhou, T. Wischgoll, Wright State Univ. (United States); L. M. Blaha, Air Force Research Lab. (United States); R. Smith, R. J. Vickery, Dynamics Research Corp. (United States)

\section{SESSION 5 MACHINE LEARNING AND DATA MINING}

9017 OB User-driven sampling strategies in image exploitation (Best Paper Award) [9017-10]

N. Harvey, R. Porter, Los Alamos National Lab. (United States)

\section{SESSION 6 USER INTERFACE AND INTERACTION}

9017 OC Collaborative data analysis with smart tangible devices [9017-11]

J. Fuchs, R. Rädle, D. Sacha, F. Fischer, A. Stoffel, Univ. Konstanz (Germany)

9017 OD Visualization of off-screen data on tablets using context-providing bar graphs and scatter plots (Best Paper Award) [9017-12]

P. S. Games, A. Joshi, Boise State Univ. (United States)

9017 OE HyFinBall: a two-handed, hybrid 2D/3D desktop VR interface for multi-dimensional visualization [9017-13]

I. Cho, X. Wang, Z. J. Wartell, The Univ. of North Carolina at Charlotte (United States)

\section{SESSION $7 \quad$ TIME SERIES DATA VISUALIZATION AND ANALYSIS}

$9017 \mathrm{OF} \quad$ Visualizing trends and clusters in ranked time-series data [9017-14]

M. B. Gousie, J. Grady, M. Branagan, Wheaton College (United States)

9017 OG Relating interesting quantitative time series patterns with text events and text features (Best Paper Award) [9017-15]

F. Wanner, T. Schreck, W. Jentner, L. Sharalieva, D. A. Keim, Univ. Konstanz (Germany)

\section{SESSION 8 MULTIDIMENSIONAL DATA VISUALIZATION}

9017 ol Visualization of multidimensional data with collocated paired coordinates and general line coordinates [9017-17]

B. Kovalerchuk, Central Washington Univ. (United States)

\section{SESSION 9 ABSTRACT RENDERING AND VISUALIZATION}

9017 0J Visual abstraction of complex motion patterns (Best Paper Award) [9017-18]

H. Janetzko, D. Jäckle, O. Deussen, D. A. Keim, Univ. Konstanz (Germany)

9017 OK Abstract rendering: out-of-core rendering for information visualization [9017-19] J. A. Cottam, A. Lumsdaine, Indiana Univ. (United States); P. Wang, Continuum Analytics (United States) 
9017 OL GlyphSea: visualizing vector fields [9017-20]

E. McQuinn, Univ. of California, San Diego (United States) and San Diego Supercomputer Ctr. (United States); A. Chourasia, San Diego Supercomputer Ctr. (United States) and Univ. of California, San Diego (United States); J. P. Schulze, California Institute for Telecommunications and Information Technology (United States) and Univ. of California, San Diego (United States); J.-B. Minster, Scripps Institute of Oceanography (United States) and Univ. of California, San Diego (United States)

9017 OM Simulation and visualization of velocity fields in simple electrokinetic devices [9017-21] P. Mahanti, T. Taylor, D. Cochran, M. Keebaugh, M. A. Hayes, Arizona State Univ. (United States)

9017 ON Streamline similarity analysis using bag-of-features [9017-22]

Y. Li, C. Wang, C.-K. Shene, Michigan Technological Univ. (United States)

INTERACTIVE PAPER SESSION

$901700 \quad$ Evaluation in visualization: some issues and best practices [9017-23]

B. Sousa Santos, P. Dias, Univ. de Aveiro (Portugal)

9017 OP Interactive word cloud for analyzing reviews [9017-24]

H. Jung, FactSet Research Systems, Inc. (United States)

$90170 Q$ Stars advantages vs parallel coordinates: shape perception as visualization reserve [9017-25]

V. Grishin, View Trends International (United States)

9017 OR Possibility space for GIS suitability analysis [9017-26]

W. Boonsuk, Eastern Illinois Univ. (United States); C. Harding, lowa State Univ. (United States)

9017 OS Improving chemical mapping algorithm and visualization in full-field hard x-ray spectroscopic imaging [9017-27]

C. Chang, W. XU, Y. K. Chen-Wiegart, J. Wang, D. Yu, Brookhaven National Lab. (United States)

9017 OT Progressively consolidating historical visual explorations for new discoveries [9017-28] K. Zhao, M. O. Ward, E. A. Rundensteiner, H. N. Higgins, Worcester Polytechnic Institute (United States)

9017 OU Comparative case study between D3 and highcharts on lustre data visualization [9017-29] O. ElTayeby, Clark Atlanta Univ. (United States); D. John, P. Patel, S. Simmerman, The National Institute for Computational Sciences (United States)

9017 OV Spatial partitioning algorithms for data visualization [9017-30]

R. Devulapalli, M. Quist, J. G. Carlsson, Univ. of Minnesota (United States) 
9017 OW Visualization of probabilistic relationships in shape-maturity data for lunar craters [9017-31] P. Mahanti, M. S. Robinson, Arizona State Univ. (United States)

9017 OX SocialMood: an information visualization tool to measure the mood of the people in social networks [9017-32]

G. Amorim, Federal Univ. of Alagoas (Brazil); R. Franco, Federal Univ. of Pará (Brazil);

R. Moraes, Federal Univ. of Alagoas (Brazil); B. Figueiredo, J. Miranda, J. Dobrões, Federal

Univ. of Pernambuco (Brazil); R. Afonso, Federal Univ. of Alagoas (Brazil); B. Meiguins,

Federal Univ. of Pará (Brazil)

9017 OY Technique and cue selection for graphical presentation of generic hyperdimensional data [9017-33]

L. M. Howard, R. P. Burton, Brigham Young Univ. (United States)

$90170 Z \quad$ Evaluation of stream surfaces using error quantification metrics [9017-34]

A. Biswas, H.-W. Shen, The Ohio State Univ. (United States)

Author Index 


\section{Conference Committee}

Symposium Chair

Sergio R. Goma, Qualcomm Inc. (United States)

Symposium Cochair

Sheila S. Hemami, Northeastern University (United States)

Conference Chairs

Pak Chung Wong, Pacific Northwest National Laboratory (United States)

David L. Kao, NASA Ames Research Center (United States)

Ming C. Hao, Hewlett-Packard Laboratories (United States)

Chaomei Chen, Drexel University (United States)

\section{Conference Cochairs}

Christopher G. Healey, North Carolina State University (United States)

Mark A. Livingston, U.S. Naval Research Laboratory (United States)

Ian Roberts, Pacific Northwest National Laboratory (United States)

Thomas Wischgoll, Wright State University (United States)

Conference Program Committee

Madjid Allili, Bishop's University (Canada)

Barry G. Becker, Pros (United States)

Daniel Cernea, Technische Universität Kaiserslautern (Germany)

Remco Chang, Tufts University (United States)

Guoning Chen, University of Houston (United States)

Yi-Jen Chiang, Polytechnic Institute of New York University (United States)

Hank Childs, University of Oregon (United States)

Jaegul Choo, Georgia Institute of Technology (United States)

Sussan Einakian, The University of Alabama in Huntsville (United States)

Christoph Garth, Technische Universität Kaiserslautern (Germany)

John Gerth, Stanford University (United States)

Matti T. Gröhn, Finnish Institute of Occupational Health (Finland)

Andreas Kerren, Linnaeus University (Sweden)

Halldor Janetzko, Universität Konstanz (Germany)

Ming Jiang, Lawrence Livermore National Laboratory (United States)

Alark Joshi, Boise State University (United States)

Robert R. Lewis, Washington State University (United States)

Guo-Shi Li, Exxon Mobil Corporation (United States)

Peter Lindstrom, Lawrence Livermore National Laboratory (United States)

Lars Linsen, Jacobs Universität Bremen gGmbH (Germany)

Zhanping Liu, Kentucky State University (United States) 
Aidong Lu, The University of North Carolina at Charlotte (United States)

Richard May, Pacific Northwest National Laboratory (United States)

Harald Obermaier, University of California, Davis (United States)

Donald A. Pellegrino, The Dow Chemical Company (United States)

Theresa-Marie Rhyne, Computer Graphics and E-Learning (United States)

Tobias Schreck, Universität Konstanz (Germany)

Chad A. Steed, Oak Ridge National Laboratory (United States)

Kalpathi R. Subramanian, The University of North Carolina at Charlotte (United States)

Shigeo Takahashi, The University of Tokyo (Japan)

Chaoli Wang, Michigan Technological University (United States)

Ming-Hsuan Yang, University of California, Merced (United States)

Caroline Ziemkiewicz, Brown University (United States)

Session Chairs

1 Biomedical Visualization

Thomas Wischgoll, Wright State University (United States)

2 Cyber Security and Visualization

Thomas Wischgoll, Wright State University (United States)

3 Text Data Mining and Visualization

Ming C. Hao, Hewlett-Packard Laboratories (United States)

4 Web-Based Visualization

Ming C. Hao, Hewlett-Packard Laboratories (United States)

Keynote Session I

Pak Chung Wong, Pacific Northwest National Laboratory (United States)

5 Machine Learning and Data Mining

Pak Chung Wong, Pacific Northwest National Laboratory (United States)

Poster Fast Forward I

David L. Kao, NASA Ames Research Center (United States)

6 User Interface and Interaction

Ming C. Hao, Hewlett-Packard Laboratories (United States)

7 Time Series Data Visualization and Analysis

Ming C. Hao, Hewlett-Packard Laboratories (United States)

Keynote Session II

Pak Chung Wong, Pacific Northwest National Laboratory (United States)

8 Multidimensional Data Visualization

Pak Chung Wong, Pacific Northwest National Laboratory (United States) 
Poster Fast Forward II

Christopher D. Shaw, Simon Fraser University (Canada)

9 Abstract Rendering and Visualization

David L. Kao, NASA Ames Research Center (United States)

10 Flow Visualization

David L. Kao, NASA Ames Research Center (United States) 


\section{Introduction}

VDA 2014 is the $21^{\text {st }}$ annual IS\&T/SPIE Conference on Visualization and Analysis. VDA covers all R\&D and application aspects of data visualization and visual analytics. This year the conference is held in conjunction with IS\&T/SPIE Electronic Imaging (EI) 2014 Symposium at the Hilton San Francisco in Union Square, San Francisco, CA from February 3 to February 5, 2014.

The conference is organized by four chairs (Pak Chung Wong, David L. Kao, Ming C. Hao, and Chaomei Chen) and four co-chairs (Christopher G. Healey, Mark A. Livingston, lan Roberts, and Thomas Wischgoll). David Kao and Ming Hao serve as the paper chairs and Chaomei Chen serves as the best paper chair. Ian Roberts manages the VDA conference website at http://vda-conference.org. The entire conference committee supports all aspects of conference organizing activities including paper review, publicity and sponsorship development, and keynote speaker invitation.

VDA 2014 received 34 submissions from around the world. Each submission received at least three peer reviews. The two paper chairs examined the reviewers' comments and selected 20 manuscripts as full papers for conference presentation. The best paper chair independently selected the five best conference papers from the accepted full papers. A special issue of extended versions of the best papers will be published in a major data visualization journal, Information Visualization (IVI). The five best VDA 2014 papers are:

1. [9017-4] Configurable IP-space maps for large-scale, multi-source network data visual analysis and correlation

2. [9017-10] User-driven sampling strategies in image exploitation

3. [9017-12] Visualization of off-screen data on tablets using contextproviding bar graphs and scatter plots

4. [9017-15] Relating interesting quantitative time series patterns with text events and text features

5. [9017-18] Visual abstraction of complex motion patterns

The conference also accepted 12 poster papers for interactive presentation on Tuesday evening from 5:30pm to 6:45pm.

The conference program for this year includes two keynote addresses on Monday and Tuesday. The two keynote speakers are Dr. Pak Chung Wong of Pacific Northwest National Laboratory and Dr. Eser Kandogan of IBM Alameda Research Center. Wong's presentation will focus on cybersecurity visualization, and Kandogan's presentation will address "just-in-time visual analytics."

We acknowledge Kitware, SPIE, and an anonymous IT company for sponsoring the conference. We also thank the paper and poster authors, program committee members, and paper reviewers for their hard work to make the 
conference a success. Finally, we gratefully acknowledge the support of IS\&T/SPIE staff for their tireless support of the conference.

\section{Pak Chung Wong David L. Kao Ming C. Hao Chaomei Chen}

